\title{
Anatomical Modifications in two Juncus Species under Salt Stress Conditions
}

\author{
Mohamad Al HASSAN ${ }^{1}$, Gholamreza GOHARI ${ }^{1,4}$, Monica BOSCAIU ${ }^{2}$, \\ Oscar VICENTE ${ }^{1 *}$, Marius N. GRIGORE ${ }^{3}$ \\ ${ }^{1}$ Universitat Politécnica de Valencia (UPV), Institute of Plant Molecular and Cellular Biology (IBMCP, UPV-CSIC), Valencia, Spain; moalhas@posgrado.upv.es; \\ ovicente@ibmcp.upv.es("correspondingauthor) \\ ${ }^{2}$ Universitat Politècnica de València (UPV), Mediterranean Agroforestal Institute (LAM),Valencia, Spain; mobosnea@eaf.upv.es \\ 3AlexandruIoan Cuza University, Faculty of Biology, Iasi, Romania; mariusgrigorepsyche@yahoo.com \\ 4Permanent address: University of Tabriz, Department of Plant Biology, Faculty of Natural Sciences, Tabriz, Iran; gohari.gh@tabrizu.ac.ir
}

\begin{abstract}
The anatomic structure of roots and culms of two Juncus species with different degrees of salt tolerance was analysed in plants grown for two months under salt stress ( $\mathrm{NaCl}$ treatments) and in control, non-treated plants. The aim of the study was not only to compare the anatomical structures of a halophyte (J. acutus) and a related glycophyte (J. articulatus), but mostly to assess whether salt stress induced anatomical modifications, by identifying differences between control and treated plants. Several slight differences have been indeed detected, in terms of endodermis type, development of aerenchyma and extent of sclerenchyma in perivascular sheaths. The role of Casparian endodermis was here discussed in relation to its complex implications in controlling salt influx at the root level that is an efficient mechanism involved in halophytes. Aerenchyma is a common feature found in marshy halophytes, allowing them to survive naturally under flooding conditions; however, when occurring in non-waterlogged plants, as is the case of this study, it should be regarded as a genetically, constitutive adaptation rather than an inducible one. Nevertheless, such anatomic modifications should be regarded as mere alterations due to stress that is, as stress responses - and not as truly adaptations to salinity. In this context, the nature of these modifications - either considered as adaptations or damage indicators of salt stress - should be further reconsidered.
\end{abstract}

Keywords: aerenchyma, anatomy, endodermis, halophytes, salt stress responses sclerenchyma

\section{Introduction}

Nowadays, the study of plant responses to salt stress and salt tolerance mechanisms is one of the most active research fields in plant biology, since salinity - together with drought - is the main constraint for agricultural production worldwide (Marcum, 2002; Munns, 2002, 2005; Ashraf, 2004; Bartels and Sunkar, 2005; Mittler, 2006). In an '-omics'-dominated era, many papers have been published reporting wide analyses of salt-induced changes, at the molecular, biochemical or physiological levels, mostly in model plant species such as Arabidopsis thaliana or some crops (Zhu, 2000; Koiwa et al., 2006; Horie et al., 2012), and lots of data have been collected that are helping to elucidate the mechanisms involved in salt tolerance. Obviously, anatomical (structural) responses to salinity of salt-tolerant plants (halophytes) have been much less studied. There are a few specific reports dealing with the anatomical features of halophytes growing in their natural saline habitats (Grigore and
Toma, 2010; Grigore et al., 2014 and reference therein), but data on possible structural modifications of halophytes in response to controlled salt stress treatments are very scarce.

A controversial issue regarding possible changes in structural features under salt stress refers to the way in which these modifications can be interpreted. Salinity is known to induce changes in plant anatomy and morphology. These changes are often considered to be adaptations which increase the chance of the plant to endure stress imposed by salinity, but they may also be regarded as signs of damage and disruption of the normal equilibrium of life processes (Poljakoff-Mayber, 1975; Larcher, 1995; Schulze et al., 2005). The anatomical and morphological features typical of halophytes are usually considered to be adaptations to salinity (Poljakoff-Mayber, 1975). Since many structural characteristics in halophytes are rather constitutive, related to their family general structural scheme and to evolution during time in relation to salinity, it is a bit problematic to regard anatomic modifications of halophytes under salt stress as an 
502

adaptation, stricto sensu (Grigore, 2012; Grigore et al., 2014). There is little experimental data to reveal whether the same features occur when halophytes are not exposed to salinity. According to Grigore et al. (2014) the action of salt on halophytes, at least in histo-anatomical terms, should be rather considered as having a formative effect in an ecological and adaptive sense. This would apply for halophytes growing in nature, while - for those cultivated under controlled conditions - these changes are still open to discussion (Grigore et al., 2014).

Maritime marshes of the Mediterranean have been described in general terms by Rikli (1943), who stated that they usually lie behind coastal dunes but are subject to salt-water inundation. Juncus acutus is a halophyte that shapes well defined plant communities within Mediterranean salt marshes (Chapman, 1960). Juncus acutus L. subsp. acutus grows in interior and littoral saline meadows, while $J$. articulatus L. subsp. articulatus is a glycophyte that occupies wet but not saline habitats in wetlands and riversides (Talavera et al., 2010). Several Iberian taxa of the genus Juncus have been the object of morphological, anatomical, biochemical, chorological and ecological studies (Fernandez Carvajal, 1981; 1982a, b; Mateu, 1991; Boscaiu et al., 2011; Boscaiu et al., 2013; Mesleard et al., 2015). Still, the direct effect of $\mathrm{NaCl}$ treatments on anatomical structures of these species has not yet been investigated.

The aim of the present study was to analyse whether high saline concentration in controlled experimental conditions, beyond the range of salinity that the two Juncus species normally face in their natural environments, has an effect on their anatomical structure. Those structural modifications, if they are indeed detected in salt treated plants, will be thoroughly analysed to establish whether they may be considered as truly adaptations to salinity, or they just represent a stress response; that is, a mere alteration induced by salt. This approach, by including species with different degree of tolerance to salinity, may contribute to a better understanding of the concepts of tolerance $v$ s. adaptation to salt stress.

\section{Materials and Methods}

\section{Plant material and experimental design}

Seeds of J. acutus were collected from a salt marsh located in the Natural Park of La Albufera (Province of Valencia, Spain) and those of J. articulatus from a non-saline area in the Natural Park. The seeds were sown directly into a moistened mixture of peat (50\%), perlite (25\%) and vermiculite (25\%) in 1 liter pots $(\varnothing=11 \mathrm{~cm})$. During the entire course of the germination process, the substrate was kept moderately moist, using Hoagland nutritive solution.

Forty-two days after sowing, salt treatments were started, maintaining half of the plants as non-treated controls. The control plants were watered twice a week with Hoagland nutritive solution (1.5 1 for each tray containing 12 pots), and salt-stressed plants with the same volume but with $\mathrm{NaCl}$ added to the nutritive solution, to a final concentration of $400 \mathrm{mM}$, prior to irrigation. Treatments were carried out over a period of two months that is sufficient to detect effects of salt stress on Juncus.

All experiments were conducted in a controlled environment chamber in the greenhouse, under the following conditions: long-day photoperiod (16 hours of light), temperature $\left(23^{\circ} \mathrm{C}\right.$ during the day and $17^{\circ} \mathrm{C}$ at night), $\mathrm{CO}_{2}$ level $(\approx 300 \mathrm{ppm})$. Humidity ranged between $50-80 \%$ during the time of the treatments.

\section{Fixation, preparation of slides and microscopic studies}

Plant material was harvested at the end of the treatments from different tissues (aerial tissue and roots), and placed directly in FAE (10\% formaldehyde, 50\% ethanol, and 5\% glacial acetic acid) for fixation (Feder and O'Brien, 1968). Dehydration through successive washes of the tissue with increasing concentrations of ethanol was performed, followed by application of histo-clear and paraffin wax. The tissues were processed using a microtome (Leica RM2025), stained with toluidine blue and analysed under a light microscope (Nikon SMZ800).

\section{Results}

\section{Effect of salt on the anatomy ofJuncus articulatus}

At root level, in J. articulatus control plants (Fig. 1 A and B), rhizodermis was largely exfoliated. The cortex was very thick and had a very weakly suberised exodermis. The cortical parenchyma was also very thick (8-10 cell layers), with very big meatuses between them; they had a squared, rhomboidal or rectangular shape. The endodermis had cells with Casparian strips slightly noticeable. The stele was very thin and had a parenchymatous pericycle. There were 13-15 xylem vascular bundles - only metaxylem vessels were easily noticeable - and the same number of phloem bundles, which were difficult to distinguish. Three-four large central vessels, without connection with those of xylem bundles, were also observed. The pith was thick, of the parenchymatous-cellulosic type.

In salt-treated plants (Fig. 1C and D), the rhizodermis had been entirely exfoliated. The cortex was thick and had an exodermis consisting of three suberised cell layers, partly exfoliated here and there. The cortical parenchyma contained cells slightly prolonged radially. The three internal layers had rectangular, overlapped cells. The endodermis was typically of the tertiary type, with lignified Casparian strips, in a horseshoe shape - the internal wall was very thick. The stele had a parenchymatous pericycle. There were 13-15 xylem vascular bundles, some of them in direct contact with the six large central metaxylem vessels, as well as 13-15 phloem bundles, noticeable only by the very large cells of the phloem parenchyma. The pith was sclerified and lignified; in its width, six large vessels of metaxylem were embedded.

Culms, which had been analysed at the basal level, had an elliptic outline. The epidermis of culms in control plants (Fig. $2 \mathrm{~A}$ and B) presented cells with the external wall thick and lignified. Here and there, small tannin and silica cells could be noticed. The cortex was very thick, of the parenchymatous-lignified type, with many cells containing silica and tannin. It consisted of $3-4$ layers of external parenchyma, with very short palisade cells, 20 small vascular bundles, numerous large air-storing cavities, prolonged radially, and 1-2 layers of internal parenchyma. The stele was thick and presented a sinuous sclerenchyma ring, which reached the periphery of vascular bundles, protruding between them. There were also about $40 \mathrm{big}$ and small vascular bundles, alternating with each other, all of them surrounded by a sclerenchyma sheath, which was thicker on the phloem area and in contact with sclerenchyma ring. In many vascular bundles, tracheogenesis process was still running. The pith was parenchymatous, with many cells containing tannin; a few central cells appeared to be in the process of disorganisation. 


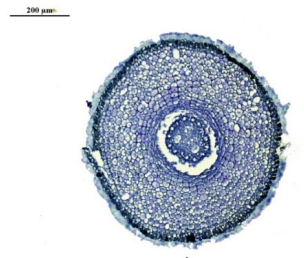

A

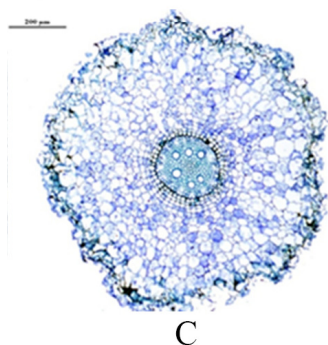

$\mathrm{C}$

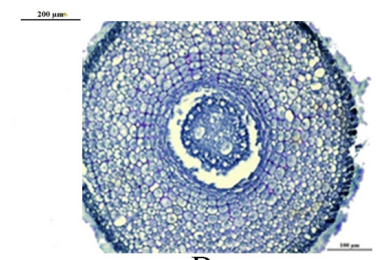

B

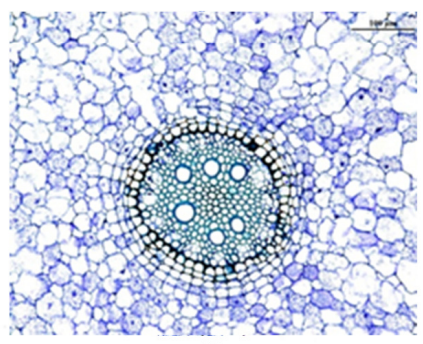

D

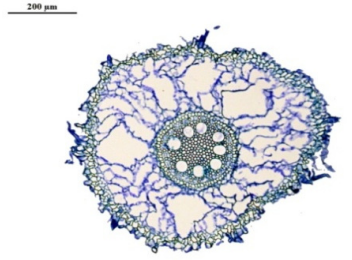

A

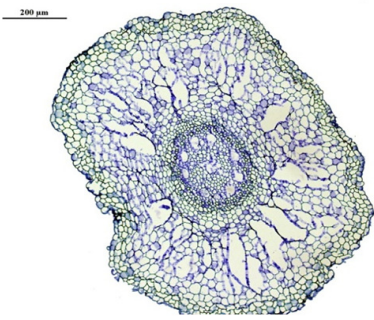

C

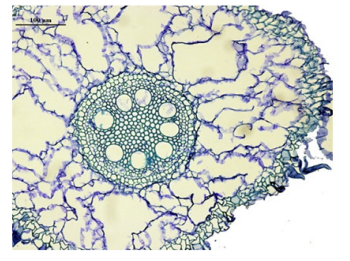

B

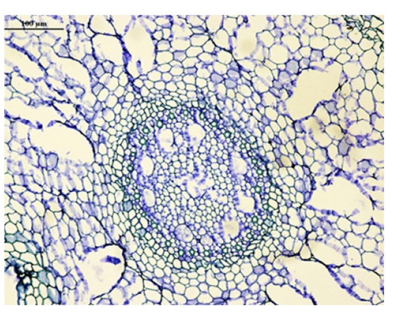

$\mathrm{D}$

Fig. 1. Cross-sections of roots in Juncus articulatus control plants (A and B) and in plants treated for eight weeks with $400 \mathrm{mM} \mathrm{NaCl}(\mathrm{C}$ and D)

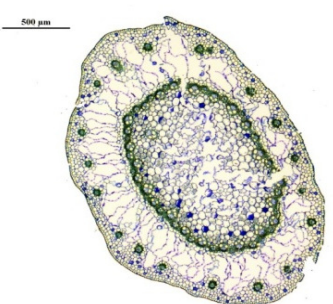

A

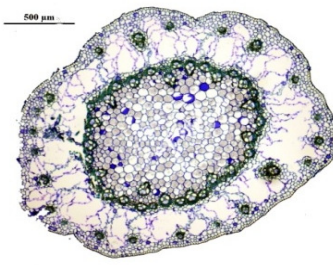

$\mathrm{C}$

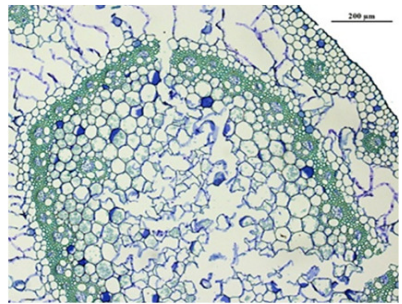

B

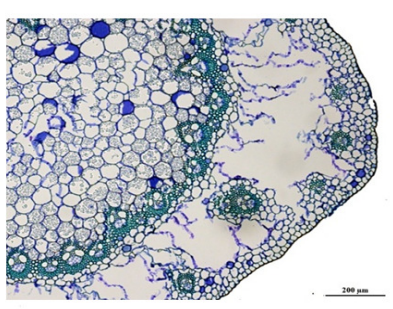

$\mathrm{D}$

Fig. 2. Cross-sections of Juncus articulatus culms, in control plants (A and B) and in plants treated for eight weeks with $400 \mathrm{mM} \mathrm{NaCl}$ (C and D)

In salt-treated plants (Fig. $2 \mathrm{C}$ and $\mathrm{D}$ ), the culm cross-section outline was circular. The epidermis had cells with external walls moderately thickened and lignified. The cortex was thicker than in control plants and presented 18-22 vascular bundles located in the outer area of the cortical parenchyma, as well as abundant air-storing cavities, strongly elongated radially and separated by fragments of parenchyma. The stele consisted of a peripheral sclerenchyma ring and 30-32 vascular bundles, from which 1-2 deeply protruded in the pith, thus losing the contact with the sclerenchyma ring. This and the sclerenchyma sheaths surrounding vascular bundles had cells with very thick walls. The pith was parenchymatous, compact, with cells containing tannin and amiliferous cells.

\section{Effect of salt on the anatomy Juncus acutus}

At the level of roots, which were adventitious and very thin, in J. acutus control plants (Fig $3 \mathrm{~A}$ and B) the rhizodermis had relatively

Fig. 3. Cross-sections of Juncus acutus roots, in control plants (A and B) and in plants treated for eight weeks with $400 \mathrm{mM} \mathrm{NaCl}$ (C and D)

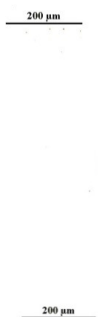

$\underline{200 \mu \mathrm{mm}}$

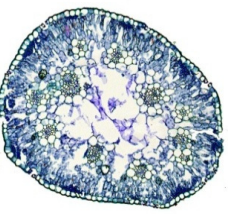

A

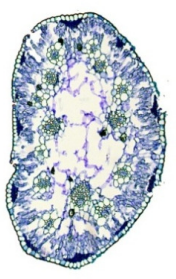

$\mathrm{C}$

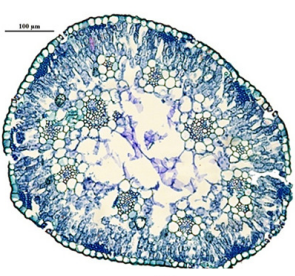

B

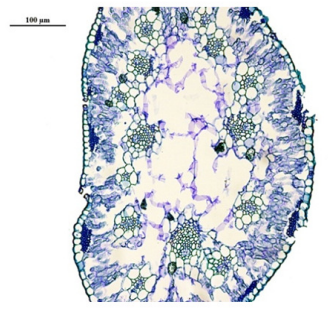

$\mathrm{D}$
Fig. 4. Cross-sections of Juncus acutus culms, in control plants (A and B) and in plants treated for eight weeks with $400 \mathrm{mM} \mathrm{NaCl}(\mathrm{C}$ and D)

short, abundant absorbing hairs. The cortex was relatively thick, including an exodermis with 2-3 layers of cells possessing thin, less suberised walls; the cortical parenchyma was thick, with many large air-storing cavities, very close to each other and separated only by fragments of disintegrated parenchymatous cells and by the stele; the endodermis had large cells, with internal and radial walls moderately thickened and lignified, which did not have yet the horseshoe shape typical for most monocots. The stele was relatively thick, consisting of a pericycle with cells smaller than those of the endodermis, with which they alternated, and with all walls being thin. In the parenchyma, which was moderately sclerified and lignified, 7-8 large metaxylem vessels were embedded, arranged in a circle. The vascular bundles, of xylem and phloem types, were difficult to distinguish, because protoxylem vessels - in contact with the pericycle - did not differ significantly from cells of sclerified and lignified parenchyma; in addition, the few phloem elements had already slightly thickened 
504

and lignified walls. Overall, at a close look, 15-17 xylem and phloem alternating bundles could be noticed. The pith was intensely sclerified and lignified.

At the same level, in the roots of salt-treated plants (Fig. $3 \mathrm{C}$ and D), the rhizodermis had few absorbing hairs. The cortex consisted of an exodermis, in the process of suberification; air-storing cavities in the cortical parenchyma were separated by radial strips of parenchyma cells; the endodermis was similar to that observed in control plants. The stele appeared thinner than in the absence of salt; in its structure, 8-10 large metaxylem vessels with very thin walls were present. Phloem bundles were not observed, but many small groups of protoxylem (whose very narrow vessels were similar to cells belonging to sclerified and lignified parenchyma) and isolated vessels in contact with pericycle could be noticed. The medullar parenchyma had cells with thin and moderately lignified walls. The stele was separated from cortical air-storing cavities by $4-5$ layers of parenchyma.

Culms, analysed at the upper level, had an oval outline in cross section (Fig. 4A and B). At this level, the epidermis consisted of cells with thick and intensely lignified external walls; here and there, stomata could be observed. The cortex comprised 9-10 strands of hypodermic sclerenchyma, of different sizes and number of components, and a palisade tissue with 2-3 layers of cells, located between and underneath sclerenchyma strands, interrupted at the level of sub-stomatal cavities. No endodermis or special pericycle could be noticed. The stele consisted of fundamental parenchyma, of the meatic type. The vascular bundles, of collateral closed types, were arranged in two rings: an external one, with small (5-6) vascular bundles and an internal one, with large (5-6) vascular bundles; all of them were surrounded by a sclerenchyma sheath, consisting of elements with moderately thickened but intensely lignified walls. The axial parenchyma was incompletely disintegrated, forming airstoring cavities of irregular outline.

In salt-treated plants (Fig. $4 \mathrm{C}$ and D), there were 10-12 hypodermic sclerenchyma strands; palisade tissue had shorter cells. Large, internal (6) and smaller, external (8) vascular bundles could be observed. Many cells from the cortical and fundamental parenchyma were partly disintegrated, thus giving the appearance of air-storing cavities.

\section{Discussion}

The anatomical features in both control and salt-treated plants fit to the general structural plan of Juncus species (Blau, 1904; Burduja and Toniuc, 1983-1984; Cutler, 1969; NappZinn, 1973; 1974; 1984; Vierhapper, 1930; Grigore et al., 2014). Several anatomical differences between the two species are evident, independently of the stress treatment. For instance, in J. acutus a well-developed aerenchyma was noticed in the root, while in J. articulatus it was absent. Since aerenchyma forms in both, control and salt-stressed plants, it should be assumed that this is a constitutive feature rather than a response to the salt treatment. Formation of aerenchyma must be related instead to the conditions where this species grows, in a marsh, where this is a common anatomical feature (Grigore et al., 2014). In the control plants, the aerenchyma seems to be in direct contact with the central cylinder, while in treated plants it is separated from the stele by several layers of parenchyma cells. Yet, it is not clear whether this difference can be correlated with the salt treatment. The possibility that aerenchyma formation can be induced by increasing salinity has been discussed by Colmer and Flowers
(2008), but there are no relevant data supporting this hypothesis. Nevertheless, there are several additional differences between control and salt-treated plants regarding their anatomical characteristics, modifications that can be assumed to be induced by salt stress. For instance, in J. articulatus subjected to high $\mathrm{NaCl}$ concentrations, the root endodermis is well developed, being of the tertiary type, with typical Casparian strips; in non-stressed control plants, on the contrary, these strips are hardly noticeable. In addition, the root exodermis of treated plants is highly suberised, while there is a weakly suberification in the controls. Grigore et al. (2014) emphasised that the exodermis, and especially the endodermis, may act as 'barriers' that can control and restrict the flux of ions to the plant organs in the presence of high soil salinity; this mechanism could contribute significantly to plant survival under severe conditions, natural or experimental. Fahn (1964) and Ginzburg (1966) studied the role played by the endodermis in these mechanisms, particularly on desert halophytes. They discovered that the Casparian strips were wide and thick in the roots of these species, and suggested that the endodermis barrier appears in a highly developed form in plants of such habitats. Poljakkof-Mayber (1975) also found that the ratio between the widths of the Casparian strips and the radial wall of endodermis cells showed large variations: from 1 in hydrohalophytes to 0.9-0.8 in xerohalophytes, and from 0.6-0.5 in dune plants, to $0.33-0.27$ in cultivated plants.

It is well known that Casparian strips of root endodermis contain aliphatic and aromatic suberins (Schreiber et al., 1999), which make the endodermis impermeable to ions and highmolecular-weight compounds, but allow the continuum of water and other low-molecular-weight solutes. Waisel (1972) showed that, in certain species, (Suaeda monoica, Vicia faba) Casparian strips cover almost the entire radial walls of the endodermis as compared to less than one-third covered in glycophytic dicotyledonous. Therefore, due to its particular wall differentiation and ultrastructural features, the primary endodermis is generally regarded as the main apoplastic transport barrier for the passive uptake of water with dissolved ions, from the soil solution into the xylem vessels located in the stele of the root (Robbins II et al., 2014). It has been stated that water and ions, which have passively moved from the soil solution to the endodermis through the cell walls of the root cortex, must penetrate the protoplast of the living endodermis cell to gain access to the central cylinder of the root (Geldner, 2013). In this way, it is assumed that root selectivity allows the separation between nutrients and harmful substances (Marschner, 1995).

The role of the Casparian strips as a barrier for solutes and ions has been suggested in several ways: the absence of diffusion of fluorescent dyes beyond the Casparian strip into the stele (Alassimone et al., 2010), by the accumulation of salts at the cortical side of the Casparian strip (Alassimone et al., 2012), and by the drop in root pressure observed after puncturing the endodermis (Peterson et al., 1993; Steudle and Peterson, 1998).

In high-saline environments, the endodermis limits free apoplastic diffusion of sodium ions into the vascular flux (Robbins II et al., 2014). Apparently, this leads to the accumulation of sodium ions in tissues located at the periphery of endodermis (Møller et al., 2009).

In addition, there are some data suggesting that the exodermis might form an important barrier towards passive apoplastic diffusion in roots (Clarkson, 1991; Grigore et al., 2014). It is well known that hypodermal cell walls are also 
incrusted with lipophilic and aromatic compounds (Peterson, 1997). In addition, in response to certain environmental factors, there the formation of Casparian strips may occur in hypodermis (Enstone and Peterson, 1998).

In the stem of $J$. articulatus, analysed at the basal level, the cortex of salt-treated plants is thicker and has many and large airstoring cavities than in control plants. However, it is questionable if developed aerenchyma has an inducible-adapted value or is just a sign of tissue damage induced by salinity that may produce a disintegration of cortical cells.

\section{Conclusions}

The anatomical modifications found in plants subjected to salt stress do not differ significantly from the general features specific for Juncus species. However, the observation under salinity conditions of a tertiary endodermis in the root, and the well-developed aerenchyma in root and stem of treated plants could suggest that these are modifications induced by salt, rather than anatomic adaptations in its broader sense.

\section{Acknowledgements}

Work in the UPV laboratories was funded by a grant to O.V. from the Spanish Ministry of Science and Innovation (Project CGL2008-00438/BOS), with contribution from the European Regional Development Fund. M.A.H. is a recipient of an Erasmus Mundus pre-doctoral scholarship financed by the European Commission (Welcome Consortium).

\section{References}

Alassimone J, Naseer S, Geldner N (2010). A developmental framework for endodermal differentiation and polarity. Proceedings of the National Academy of Sciences 107:5214-5219.

Alassimone J, Roppolo D, Geldner N, Vermeer JE (2012). The endodermis: development and differentiation of the plant's inner skin. Protoplasma 249:433-443.

Ashraf M (2004). Some important physiological selection criteria for salt tolerance in plants. Flora 199:361-376.

Bartels D, Sunkar R (2005). Drought and salt tolerance in plants. Critical Reviews in Plant Sciences 24:23-58.

Blau J (1904). Vergleichen-anatomische Untersuchung der Schweizerischen Juncus Arten [Comparative anatomical study of the Swiss Juncus species]. Lisz, Zürich.

Boscaiu M, Ballesteros G, Naranjo MA, Vicente O, Boira H (2011). Responses to salt stress in Juncus acutus and J. maritimus during seed germination and vegetative plant growth. Plant Biosystems 145:770-777.

Boscaiu M, Lull C, Llinares J, Vicente O, Boira H (2013). Proline as a biochemical marker in relation to the ecology of two halophytic Juncus species. Journal of Plant Ecology 6:177-186.

Burduja C, Toniuc A (1983-1984). Données céno-écologiques et histoanatomiques sur les espèces Juncus acutus L. et J. maritimus Lam. Acta Horti Botanici Bucurestiensis 93-96.

Chapman VJ (1960). Salt marshes and salt deserts of the world. Leonard Hill Interscience Publishers, New York.
Clarkson DT (1991). Root structure and sites of ion uptake. In: Waisel Y, Eshel A, Kafkafi U (Eds). Plant roots: the hidden half. Marcel Dekker Pub pp 417-453.

Colmer TD, Flowers TJ (2008). Flooding tolerance in halophytes. New Phytologist 179:964-974.

Cutler DF (1969). Anatomy of the Monocotyledons. Vol 4, Juncales. Clarendon Press, Oxford.

Enstone DE, Peterson CA (1998). Effects of exposure to humid air on epidermal viability and suberin deposition in maize (Zea mays L.) roots. Plant, Cell and Environment 21(8):837-844.

Fahn A (1964). Some anatomical adaptations of desert plants. Phytomorphology 14:93-102.

Feder N, O'Brein TP (1968). Plant Microtechnique: Some principles and new methods. American Journal of Botany 55(1):123-142.

Fernandez-Carvajal MC (1981). Revisión del género Juncus L. en la Península Ibérica. I. Categorías supraespecíficas y clave para las especies. Anales del Jardín Botánico de Madrid 38(1):79-89.

Fernandez-Carvajal MC (1982a). Revisión del género Juncus L. en la Península Ibérica. II. Subgéneros Juncus y Genuini Buchenau. Anales del Jardín Botánico de Madrid 38(2):417-467.

Fernandez-Carvajal MC (1982b). Revisión del género Juncus L. en la Península Ibérica. III. Subgéneros Subulati Buchenau, Pseudotenageia Krecz. \& Gontsch. y Poiophylli Buchenau. Anales del Jardín Botánico de Madrid 39(1):79-151.

Geldner N (2013). The endodermis. Annual Review of Plant Biology 64:531-558.

Ginzburg C (1966). Xerophytic structures in the roots of desert plants. Annals of Botany 30:413-418.

Grigore M-N (2012). Romanian salt tolerant plants. Taxonomy and Ecology. Tehnopress, Iasi.

Grigore M-N, Ivanescu L, Toma C (2014). Halophytes. An integrative anatomical study. Springer, Heidelberg, New York, Dordrecht, London.

Grigore M-N, Toma C (2010). Structuri secretoare de săruri la halofite. O abordare integrativă [Salt secreting structures of halophytes. An integrative approach]. Ed Acad Rom, Bucureşti (in Romanian).

Horie T, Karahara I, Katsuhara M (2012). Salinity tolerance mechanisms in glycophytes: An overview with the central focus on rice plants. Rice 5:11 doi:10.1186/1939-8433-5-11.

Koiwa KH, Bressan RA, Hasegawa PM (2006). Identification of plant stress-responsive determinants in arabidopsis by large-scale forward genetic screens. Journal of Experimental Botany 57:1119-1128.

Larcher W (1995). Physiological plant ecology (3 ${ }^{\text {rd }}$ edition). Springer, Berlin, Heidelberg, New York, Barcelona, Budapest, Hong Kong, London, Milan, Paris, Tokyo.

Marcum KB (2002). Growth and physiological adaptations of grasses to salinity. In: Pessarakli M (Ed). Handbook of plant and crop physiology ( $2^{\text {nd }}$ edition). Marcel Dekker Inc, New York, Basel pp 623-636.

Marschner H (1995). Mineral nutrition of higher plants ( $2^{\text {nd }}$ edition). Academic Press, San Diego.

Mateu AI (1991). Leaf anatomy of plants from coastal Mediterranean salt-marshes. Monocotyledons. Candollea 46(2):345-358. 
506

Mesleard F, Yaverkovski N, Dutoit T (2015). Photoperiod buffers responses to salt and temperature during germination of two coastal salt marsh colonizers Juncus acutus and Juncus maritimus. Plant Biosystems doi:10.1080/11263504.2015.1007898.

Mittler R (2006). Abiotic stress, the field environment and stress combination. Trends in Plant Science 11:15-19.

Møller IS, Gilliham M, Jha D, Mayo GM, Roy SJ, Coates JC, HaseloffJ, Tester M (2009). Shoot $\mathrm{Na}^{+}$exclusion and increased salinity tolerance engineered by cell type-specific alteration of $\mathrm{Na}^{+}$transport in Arabidopsis. Plant Cell 21:2163-2178.

Munns R (2002). Comparative physiology of salt and water stress. Plant Cell and Environment 25:239-250.

Munns R (2005). Genes and salt tolerance: bringing them together. New Phytologist 167:645-663.

Napp-Zinn KL (1973, 1974, 1984). Anatomie des Blattes. II. Angiospermen. In Handbuch der Pflanzenanatomie. 8, 2A(1-2);2 B1, Gebrüder Borntraeger, Berlin, Stuttgart.

Peterson CA (1997). The exodermis and its interactions with the environment. In: Flores HE, Lynch JP, Eissenstat DM (Eds). Radical biology: Advances and perspectives on the function of plant roots. American Society of Plant Physiologists pp 129-138.

Peterson CA, Murrmann M, Steudle E (1993). Location of the major barriers to water and ion movement in young roots of Zea mays $\mathrm{L}$. Planta 190:127-136.

Poljakoff-Mayber A (1975). Morphological and anatomical changes in plants as a response to salinity stress. In: Poljakoff-Mayber A, Galle AJ (Eds). Plants in saline environments. Springer, Berlin, Heidelberg, New York pp 97-117.
Rikli M (1943). Das Pflanzenkleid der Mittelmeerlander (Vol 1). Huber, Bern.

Robbins II NE, Trontin C, Duan L, Dinneny JR (2014). Beyond the barrier: communication in the root through the endodermis. Plant Physiology 166:551-559.

Schreiber L, Hartmann K, Skrabs M, Zeier J (1999). Apoplastic barriers in roots: chemical composition of endodermal and hypodermal cell walls. Journal of Experimental Botany: 50:1267-1280.

Schulze ED, Beck E, Müller-Hohenstein K (2005). Plant Ecology. Springer Verlag, Berlin, Heidelberg.

Steudle E, Peterson CA (1998). How does water get through roots? Journal of Experimental Botany 49:775-788.

Talavera S, Gallego MJ, Romero Zarco C, Herrero A (2010). Flora Iberica. Plantas vasculares de la Peninsula Iberica e Islas Baleares (Vol XVII), Butomaceae-Juncaceae. Real Jardin Botanico, CSIC, Madrid.

Vierhapper F (1930) Juncaceae. In: Engler A, Prantl K (Eds). Die natürlichen Pflanzenfamilien (Vol 15A). Engelmann ( $\left.2^{\text {nd }} \mathrm{Ed}\right)$, Lepzig pp 192-222.

Waisel Y (1972). Biology of halophytes. Academic Press, New York, London.

Zhu J-K (2000). Genetic analysis of plant salt tolerance using Arabidopsis. Plant Physiology 124:941-948. 